\title{
The Arab Occupation of Crete
}

THE period of the Amorien dynasty (820-87) is, in consequence 1 of the scantiness of our sources and the pauaity of dates and abence of chronologional order which wo find in them, perheps the most obsoure in the annals of the eastern empire; and in this period not the least obscure event is the Arab conquest of Crote. That the conquerors were adventuress from Spain, who, having been benished from that eonntry after a sedition in 814, sailed to Egypt and seired Alerandria, from which they wero expelled by 'Abd Allah ibn Tahir, is well known; but the whole story is told by Arabio writers only, the Groek anthors saying nothing of Egypt, and sooming to think that the conquerors came direct from Spein. On the other hand, for the fact of the conquest itself, with the exception of three lines of Al Baladhuri (c. 870), in which it is merely stated that the Arab leader, Abr Hafs, took a fortreas and sottled in it, and then conquered the rest of the island, one place after another, and destroyed the fortresses, ${ }^{1}$ wro depend entirely on Greels sources. Al Baledhwri, acoording to a citetion in Yequt's Geographical Dictionary, ${ }^{2}$ pleced the conquest of the islend in A.H. 210 (24 April 825-12 April 826); but, so the date is not in either of the existing manuscripts, its originality must be donbtful. According to Al Ya'qubi, who prote sbout 880 , the captare of Alorandrie

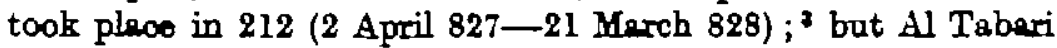
(d. 923 ) pleces it in 210, though he mentions, another acount which pleced it in 211 (13 April 828-1 April 827); ${ }^{4}$ while of the Greek authors George the Monk only states that the Arabs conquered Crete during the reign of Theophilus (829-42), the Logothete seys that Crete and Sicily were occupiod at the timo of the rebellion of Thomes (821-3)," though the Arab lending in Sicly is deffnitely fixed to 827 , and Genesius that daring this robellion the adventurers plundered Creto and in the nort year came beck and occupied it." Accordingly modern scholars havo

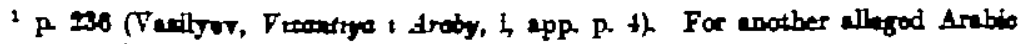
acconont an bebow, p. 4 ses.

21297 .

- i而. 1001 .

- Goort Yon., ad Bonn, p. 780.

I 4561 .

3 Ed Do Boor, p. T08.

IEd Bonn, p. 4 .
} 
generally followred Al Taberi and dated tho conquest in 825 or 826." The Syriec chronicler Micheel, however, agroeing with Al Ye'qubi, tolls on that 'Abd Allah laid siego to Alerendris in Merch 827 and took it after nino months, i. 0 . in December 827 ; and, as he follows the petriarah Dionyrius, who was in E8ypt with the caliph in 832,10 his athonity would secm to be decisive, in wite of the fact that he did not know where the adventureas went when they left Alexandris, but represents them as roturning to Spein. If, however, eny confirmation is required, it is provided, as far as the year is conoerned, by the Egyptien hirtorien Al Kindi (d. 961), rocently publiahed by M.r. R. Guest, who pleces the fall of Alexandria in Rebi' I, 212 (31 Mey-29 Juno 827)." The second date given by Al Tabari is corroct for the errival of 'Abd Alleh in Figypt, but ho has omitted to allow for the fact that hil campaigne in that country lested two years. As regurds tho month, it seem beot to give the preference to Afichnel, and plece the expulsion of the Spanish refugees trom Alexandive in December 887, and ooneoquently their in vacion of Crete in 828.12

This deto being accopted, it remains to 800 how it can be fitted in with the narratives of the Groek writers. Of these George and the Logothete merely mention the fact of the conquest, while the Continuntor of Theophanes for the most part parephrases Genesius ; and to Genesias, therefore, the flest pleos must be giren. This writer tells us that in the year before tho conqueat tho adventurers hed raveged the inland: but thoy can herdly heve come during the siege of Alexandris, and the stetement cannot be recomciled with his aevertion, corrobornted by the Logothote, thet the atteck took place during the rebellion of Thomes. If this in to bo taken literally, the raid must bo dated not later than 823, though, if wo take the civil prar cansed by the rebellion to be meant, we may postpone it to 824. It is, of courses poesible thet more than one raid was mado; but the

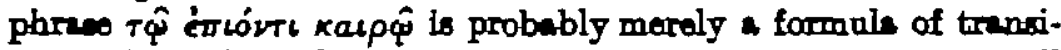
tion and not dopendent on eny authority. Ho then goes on to toll the story of how the Arab leader Abu Hefs, on lending to Creto, burned the ships in order to prevent his men from returning, and on their protesting that it woold separate thom from their riven, answered that they could find wives in the country ; but this story can hardly be reconciled either with the teot that they had been axpelled from Alerandria (of which Genesius

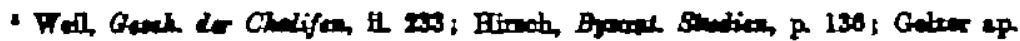

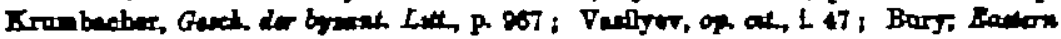
Bomisn Empire, p 2038.

- Ed Chebot, P. SLE.

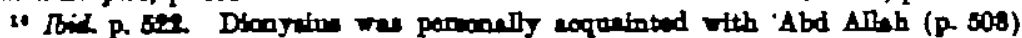

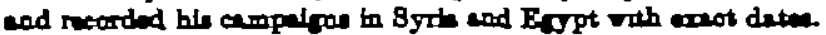

12 $\mathrm{P}$. 184

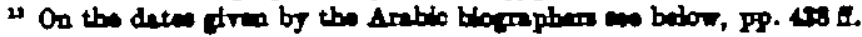


was igmorant) and must tharefore be presumed to have brought their wives with thom, or at any rate conld not return, or with the fact that immediately afterwards wo find them revaging the Aegean. ${ }^{3}$ Genesius then states that Craterus, orparmpos of the Gibyrrheoots, was sent againet the in vaders end won a victory, but, se he neglected to keop a guard during the night, his force was annibilated by an unerpected atteck, and ho elono escaped in a merchent-ship, but the enemy pursued him in tro s̀xádss, anght him, and arucified him in Cos, after whioh Oaryphes collocted a neval force and expellod the mereaders from the other inlends which they were revaging. ${ }^{14}$ Ho then reoord the death of Micheal II (October 829).

Within the spece of twenty-two monthe, therefore, wo must, if this narrative is eccopted, comprea the voyago from Alorandrin to Crete, tho flrot sucoseses of the invaders, the conveyance of the nows to Conetentinoplo, the tranemiesion of arders to tho Cibyr-

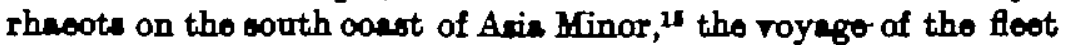
to Crote, the dofent and death of Craterus, the ravaging of tho islande, the colleotion of a floet by Ooryphes, and tho expulsion of the Arabs from the other inlends. This is difficolt enough; but tho difficulty is further increased by a notice of the Cantinuntor under the reign of Theophilo, in which ho tells as that at the time of the acossion of Theophilus, in October of the 8th indiction (829), the Romen fleot was annibilated by the Arabs off Thasos. 20 This eract date must olearly bo ecoepted, and it leaven no room for the activity of Ooryphas: for the raveging of the Aegean cemnot have seriously begun before 829 , and it is absurd to tell us that a now force was collected and the isinnds cleared, if the floot was destroyed in October.17 Obviously the mensures of Ooryphes were teken whein there was no fleot in the Aegenn, for otherwive it rould not hevo beon necensary to make a mociel lovy, and the men would not heve embarked on $\delta \lambda$ kádes; and his cotion therelore followed the battlo of Thesos. This date does not involvo eny real departure from tho narrative of Genesios, for he does not montion tho battlo; and, though he shovld trictly heve recorded the successes of Ooryphes under the reign of Theophilus, it in netural thet he should relete them where he does in order to avoid interrupting the narrative. The conse

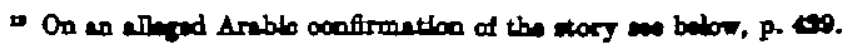

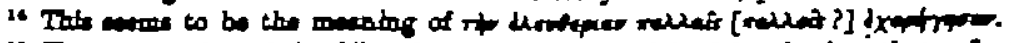

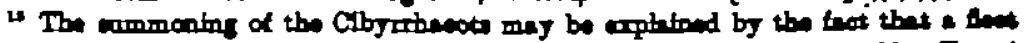

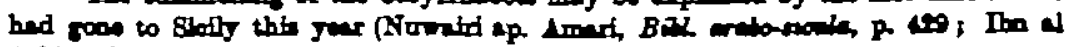
Ather, id Tormberc of 257 - Ameri, p. 203).

16 Theoph Cont If 39

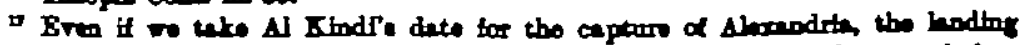

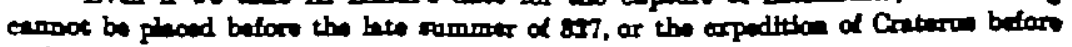

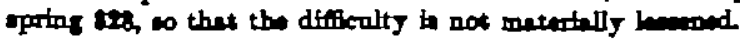

VOL IXIII- IO. CII. 
of erents is then quito clear. The Arabo landed in Crote early in 828, during tho summer or early eutumn Craterui sttecked them and was defeated, his floet probebly being captured or destroyed, in 829 they sot out to attack the other islands, and in Ootober ennihileted the Aegean squedron off Thesos. After this the inland for a time lay at their mercy ; ${ }^{13}$ but Ooryphes collected a now force end eventanlly rucceeded in protecting tho Aegeen from their ravages; bat how long they carried on their raids unchecked, or how long he was able to hold them at bey, wo do not know."20 In 841, as wo shell see, they were raiding Asiv Minor. It in not nowery to suppose thet they hed completed the conquest of Croto before beginning the raids in the Aegean. It appears both from $\mathrm{Al} \mathrm{Baladhuri}$ and from Genexius that the procen took some time, ${ }^{n}$ and George the Monk pleces the conquest in the reign of Theophilas; bat on the deteils of it wo have no information.

As far, then, as Genesius is concerned, no serions difficulty arises from the later date for tho lending : but the Continuator, while otherwise repeating his narrative, inserts before the orpedition of Creterus a story to the effect that Photinus, general of the Anetolics, great-grandfather of the Empros $\mathrm{Z}_{\infty}$, the mother of Constantine VII, was sent to Crete as governor, and, on his esking for amistence, Damien the constable was sent with a considerable force, but the Arabs won a great victory, Damian being killed and Photinus esceping alone in a bost; in spito of his ill-rucoses, however, he wes appointed orparmpós of Sicily." This Photinus, Ameri (following suggestion of Ceussin do Perceral D) identifled with tho Sicilian orparmyós who was captared and put to death by the rebel Euphemias, whom the Arabio writers call Constentine, pointing out that in Al Nurairi the name in incorrectly transliterated and appears in a form that does not greatly differ from 'Photinus'." As, howover, the Arab invasion of Sicily was certainly in 827 , end the death of the general cannot therefore be pleced later then 826, now that

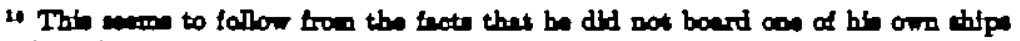

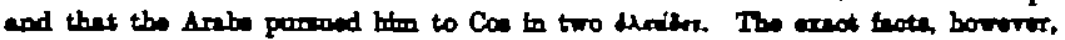

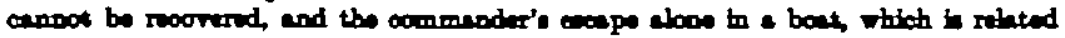

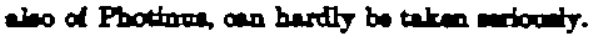

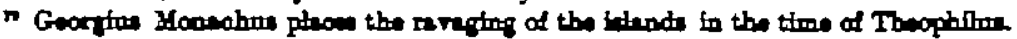
Tbo Lopothece, an the other heod, stated thet the Cyciedin, Hike Crote and Bloly, were cocouplad dacins the robelition of Thomes.

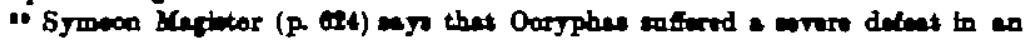

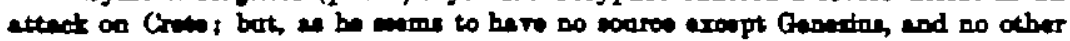

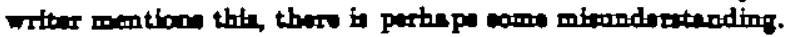

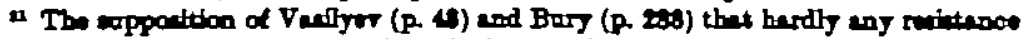

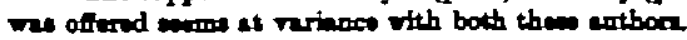

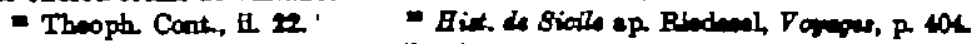

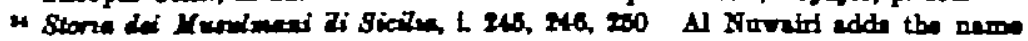
'Sode', which remtods wa the Sodeled of Theoph Cont. 1v. 16, who may here been bis won. 
wo heve esteblinhed the true deto of the inverion of Croto, it follows that the identification can only bo mainteined if wo suppose thet Photinus was sent to Crete at the timo of tho reid which proceded the Arab occapetion. But it is diffloult to think that the Anatolic general would bo transterred to tho petty commend of Crote for to trumpery a purpose, whiah woold naturally tall within the ophere of one of the naval orpartproi, nor, indeed, would there heve been time to bring him to far.

Ameri's identiflontion, indeed, though it hes been generally scoopted," was nover very convinoing, "x and thero aro evereral ressons againet it. In the first pleco, the Continustor was specielly interested in Photinos on acoont of hil retutionship to hil imperial petron, and therefore, if Photinus pleyed wo important a pert in connerion with the robeition of Eapheonitu, which this enthor reletes from tho contemporary work of Theognoutras," it if atrenge thet he should omit all mention of him. Seoondly, it most bo asrumed that a men who had hold the high office of Anatolic general wrould be a men of middlo ago; and it mart equally be esumed that $Z_{00}$ was at the time of her con's birth in 800 a young women. Hence it follow that the dirtance of time between the Creten expedition of Photinas and the birth of Constentine VII in not three generations, bat little, if anthing, more than two; and, as in thet timo and oowntry people married eartier then with w, eighty years in a mont unlikely time to allow. Profeser Bury betioves that the nerretive of the Cretan expedition is also totren tram Theognoutral: but the reletionship of Photinus to Zoo must in eny case be a family tradition dorived from tho emperor, and it neems mant obvious to suppow thet the phole story comes from this souroe." In this ase no dete woold be mentioned in the tradition, and the enthor inserted it at this point becenses, as Photinus was ent to expol the Arabs, ho supponed thet the expedition took pleos immediataly after tho lending of the invadern, though, if it really heppened at this timo, Geneaiw would not heve been ilkoly to anit it. The ideutifiation of Photinns with 'Constentioo Sude" munt therefore be sbandoned, and wo must bolk for another date at which to plece the expedition of Photinus to Crote and hir government of Sioily.

The relationship of Photinus to Zoe woold ween to fix the deto

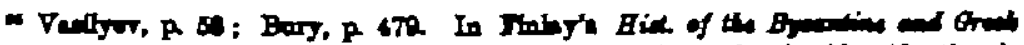

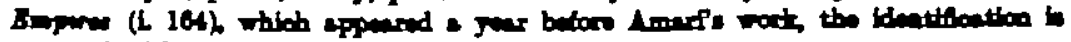

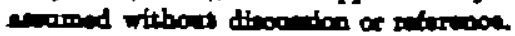

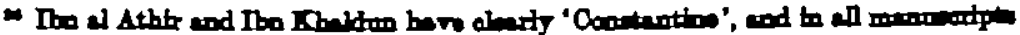

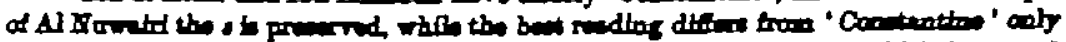

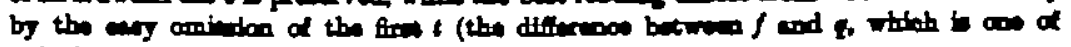

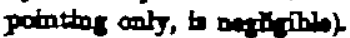

2 且 27.

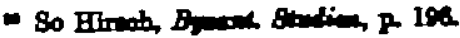


of the Creten opisode to some time between 840 and 860 ; and of these year 840 and 841 mey bo ralod out by the castern complicetions, which make it most unlikely that the Anetolio general wrould be then tranoferred to Crote, eren if sroh an oxpedition were undertaken at $\mathrm{all}$, and 843 by the expedition of Theoctistus : " the fact that Theoctistas was to Croto in 843 also makes the years 842 and 844 improbablo. Again, in the sutumn of 859 Constentino Contomytes carne to Sicily as orparmpos, ${ }^{x}$ and the appointment of Photinus to the same past cen therefore herdly heve been leter then 858 or his Creten expedition then 857. Farther, Photinus can soarcely hevo gono to Creto to the capecity of Anutolio general, and wo mant therofore asume that ho wres eppointed orparprós of Crete, as in fact the Continuator Arab ocoupetion been ruled by en apXov, ${ }^{2}$ the orparty is would weem to have been areated for the beneflt of Photinus," who, heving been orparmyós of the Anatolios, contd not be dograded to - lower rank But a orparmpos of Creto sppears in tho Taktikon of Uepenety," which was composed under Mlioheol end Theodora, and therefore not later than March 856. Hence it follows that the expedition to Crete wes not later then 855 ; and, as it soms improbablo thet Bardes would have sent en unoucesoful nominee of Theodore to commend in Sicily, I think wo must plece it not later then 864. Of the ten year which remein 845 is not an unlikely date, for at thet time there was an armistice in tho east, and the fact thet reinforcements were sont to Sicily that year ${ }^{2}$ is not a very serious objection, for the Romens may well have seired tho opportanity to make attompte to recover both islands : but in fect, with the exception of the operations undertation at the time of tho Armenien revalt in 851 , no verious fighting went on in the asst till 855, and there is enother date during this period at whioh there is much to bo aid for plecing the expodition of Photinus. We loem trom Al Teberi $*$ that in 858 throe equadrons were sent out, one of which, under a commender whow name appears in the text as Ibn Q(a)tune, sacked Damiotte (22 May)

- Georg Man, od. Bann, p. 814

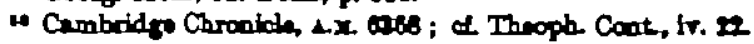

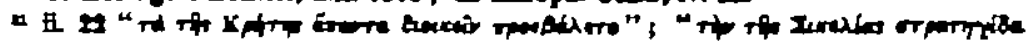

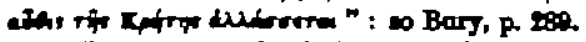

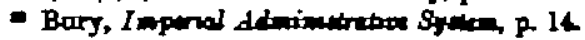

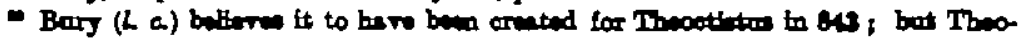

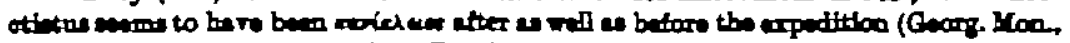

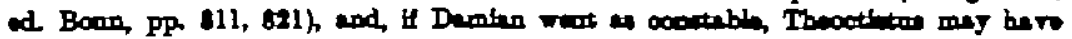

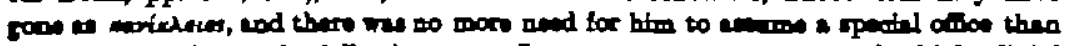

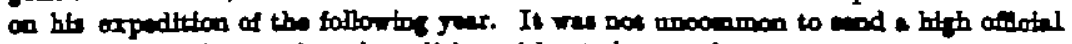

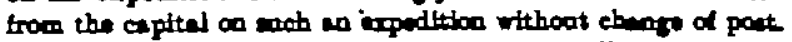

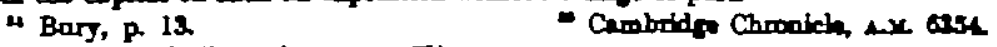

* HL 1417 (Fandyor, L app, P. 51) 
and carried off a store of arm intended for the Creten Arabs, while the dentination of the othar two, the name of the commenders of whioh mey be read as 'Urif' (Ooryphes) ${ }^{2}$ and Amardineqah (Hertinecius) is not stated. Now it sooms unlikely that three equadrons would be sent out merely to loot; and we aro perchepe therefore entitled to infer that the seirure of the arms was not an incident of the expedition but its object, and that the other squadrons avilod to Syrien ports from whioh it was bnown that arme were likely to be hipped to Crote. In this caso we can herdly but assume thet an attack upon tho oxsmins was being prepared : and, if 20 , this atteok, if carriod out, must havo taken pleoo in 863 or 851 ; indeed, as the nemo transliterated Qutrune may by the omiacion of a point be read Putrome or Bitume, and 'Ibn' is amitted in one of the two menuacrtpts which contain this persage and in Al Ya'qubi, who reoords the expedition from another sourco," it is tempting to see in the mysterious " $\mathrm{Ibn}$ Qutrone' the very Photinu whow histary wre aro sooking to unrevel, and to suppose that the descont upon Croto was mado on hin retaun fram Egypt," and therefore in 853. This, however, is conjectural, and all thet an bo affirmed on any solid ground is thet the Croten expedition of Photinus took place during the years 845-54. The name Micheel given by the Continuator to the emperor ander whom ho was gent may then heve been part of tho tradition, and his error heve erisen from supposing tant Micheal II was intended instoud of Micheal III.

It hes been notul to place at the beginning of the reign of Theophilus" 1 raid upon Asis Minar mentioned by the continuetor, in which the raiders wero cut to pieces by Constentine Contomytew, the Threcerian general. Tho reason for this is apperently that the euthor narrates it immediately before the battio of Thesos: but bo is not priting in ohronological order, and pleces no noto of connexion between the two erents, while, on the other hand, he staten thet it ocowred about the same time as the evente lant recorded, which wre the deaths of Theophobus and Theophilus (Jenuery 842); and I seo no reason to

- Bama ed Teb.

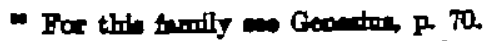

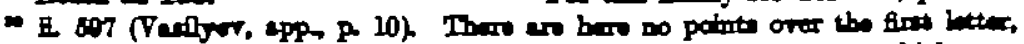

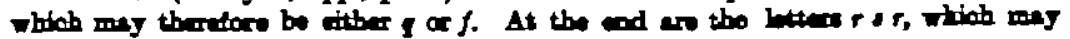

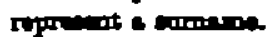

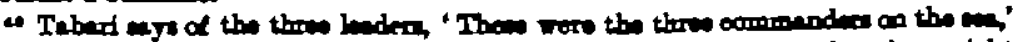

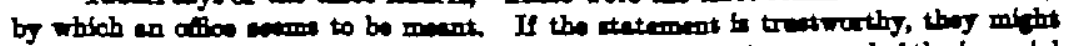

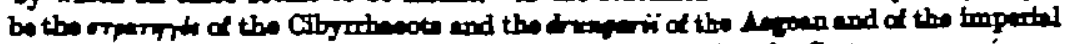

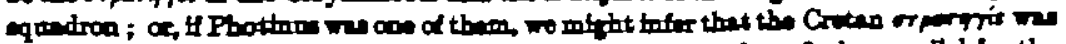

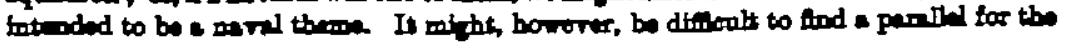
eppotoriment $\alpha$ a nilltery ofloce to a anval commend.

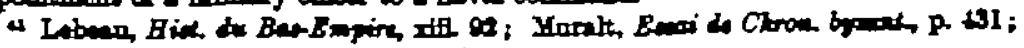

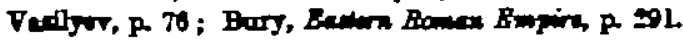

- Theoph Cont. ill 39 . 
reject this date, which sques better with the fact that Constentino Contomytes ras appointed orparmior of Sicily in 850. - It wes, however, unaral to metro expeditions in the winter; and therefore, if any confidence is to be pleced in the note of time, the ovent munt be deted in 811 .

I heve stated above thet for the dotails of the Arab conquest of Crote wo havo, with the excoption of three lines of Al Beledhuri, Greak anthorities only. Conde, however, aite narrative in which the borning of the ship is described as from the biogrephical diotionary of the Speninh $\Delta$ rab Al Humaidi (d. 1095) ; " and on the atrength of this citation this author hes been socopted as corrobaretiog the otory of Genecius." Nar onty ono menuscript of Al Humeidi's worte is known to exdit, and that is at Orford; and Profemor Mergoliouth, who has most bindly examined the mannecript for me, cescres mo thet in the pasage which Conde oites this contains nothing that is not in the work of Al Humnidi's copyist and continuetor, Al Dhabbi (d. 1203), whioh wes poblished by Codere and Ribere in 1886 from an Escorial M8., the only one known to exist in Errope; and ho Iso points out thet it eppears from Conde's own profece that he know Al Humaidi only through Al Dhabbi." Wo mey therefore be quito confldent that in the extract from $\mathrm{Al} \mathrm{Dhabbi,} \mathrm{of} \mathrm{which}$ I givo a tranalation below, 4 we have all tho information that was at Condo's dieposel.

Umar tho won of ghrieib Abu Hafi who was called "Al Ghalix';" Al Balluti, from the dirtriots of Fabs al Ballut near Cordora. Ho is mentioned by Aba Hrahemmed the son of Hasm," and be ways that bo camo from Qull al Rebadhiyin, " and that it was bo who medo the expedition to Crote and conquered it after the yeur 200 [18 Soptember 814-7 Septamber

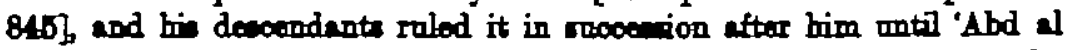
'A is tho won of Bhr'sib was the leat of them, in whowe deys Bomengs the won of Constantioe, ling of the Romans, took powcerion of it, in the yoar 350 [90 Fobrunsy 961 - 8 Fobruary 968] and moat of thow who joined him in the conquent were men of Spain. This is what be angs. And be is men-

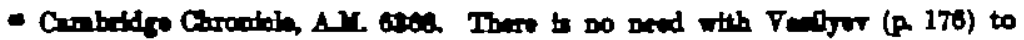
ponteolet tro mon of the neme.

4 Las drave on Erpale (d 184t) I mas.

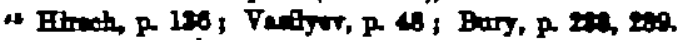

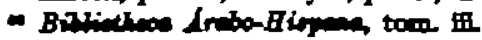
- p Iriti

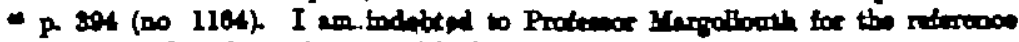

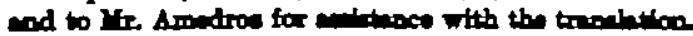

it La. 'the rough'.

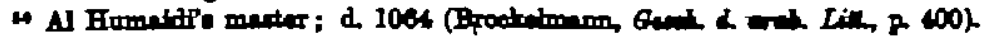

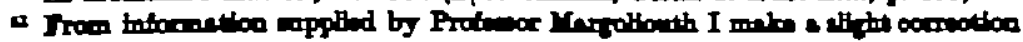

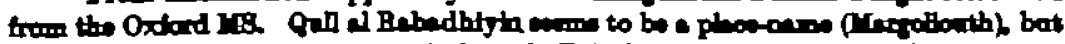

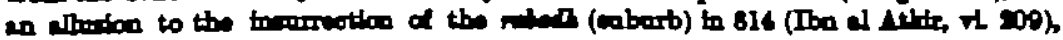

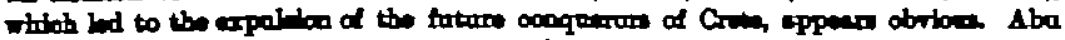

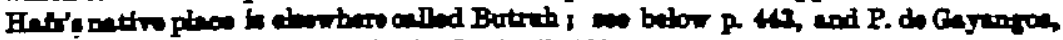

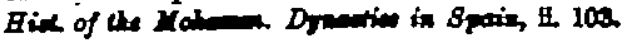


tioned by $A b a$ Sa'id the en of Yuna," and ho ans: "Shn'aib the wn of 'Umer the son of 'Ise Abn Umer, lord of the irened of Croto, cerried ont the conqueet of it after the year 2920 [5 Jenuary-28 December 835]; and this Shr'erb und to write in Al Irag, and be wrote under my grandfather Yunu the son of 'Abd al ATe a ad others alo in Egypt.' This is the end of the words of Ibn Yonus. Now theso mon differ as to his neme, One reying ' "Umar the son of Bhr'aib', and the otber aying 'Bhu' uib the won of 'Umar', end both deroribe bum se the conqueror; if thet were not 20 , wo shorld hero asid thet one of thom was the won of the other : and it mey be thet both were present at the conquest : if it un not $\infty$, there hes been a transporition in the cese of one of them. God known.

Conde oorrectly introduces this notice with the rords 'cuente Edobl', but he then gives as part of the citation the statement that the inswrgents after their expolsion chow Abn Hafs as their leeder, which is not in the tert ; instead of "Abn Mnhammed ibn Herm' ho writes 'Seid ben Jones', omitting the real citation from Tbn Yumus, and at the and he writes 'And lo refiero Homeidi citando \& Muhemed ben Hurem', though he hes just given 'Said been Jonas' as the suthority ('Abu' he seems to consider - superfluour prefix). These are only instances of his habitual inecouray : but he then goes on to repeat on the euthority of Al Humaidi the atory of the conquest almost as it appears in the Greek writers, the only statements of fact not contained in these being the mention of Sude instesd of Charax as the lendingplece and the locslizetion of Candin at the east end of the island; and both theso, as well as certain literary embelliahments, aro also to be found in Gibbon, while no doteil of the Greek thet is proserved by Conde is abent trom Gibbon, and both writers, whilo otherwise following Genesins, insert the allusion to future children from the Continator. To make the matter quite olear, I plece the paseages of Gibbon and Condo in parallol columns, printing in italices expresions abent in the Greek text which are oammon to both writers.

Grobos, ad. Bury, vi. 37.

$\Delta$ band of Andelarien rolmtears ... explored the edventures of the ree; but, 21 they aulad in no more then 10 or 20 gallogen, their wathro muit be branded with the nemo of piracy. . . From the morth of the Nive to the Hellewpont, the inlends and ma-conets, both of the Grocks and Mouleme, wero expowed to their
Cosme (d. 1844), i. 206.

As lo refiero Homeidi citando 1 Yuhnemed ben Huram, y ouents

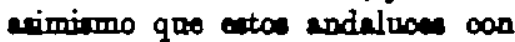
veinte neves comen $\mathrm{I}$ robeben on el mar griggo $Y$ on sus islas :

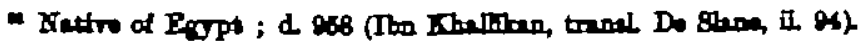

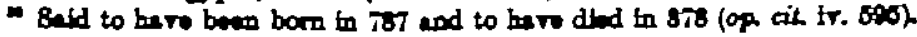


deprodetione. . . The Andeluriens whidered over the land fearlen and unmotested; but, when they docoended with this plusider to the mothore, their vemels wore in finmes, and their ohiof, Abu Caeb, confened himsolf the euthor of the mimohiof. Their elemour eocused hil mednew or treechery. 'Ot whet do you compluin "' roplied tho enfty emir. "I hero brought you to a land flowing with milk and honey. Haro is your tron country: ... torgot the berren ploce of your mativity.' 'And our wives and children ?' 'Your beowdeous coptive will supply tho pleco of your riven and in thair mbraces you vill won becomo the fathers of a now proseny.' Their flest hebitetion was tbeir cemp ... in the bey of Sula:"th but an epontate mont led them to a... position in the castern ports; and the name of Cunder, their ... colony, hed [her ?] been extended to the whole inlend. dion quo decenndo ello por el netaral emor it su petrie tormar a olle con las muluas rechesas que habian allogedo, que an candilto les quemo le flote, $y$ como wo quijesen de bl y do re constente doterminacon, lementindowe de so destierro, que ol candillo les dijo:

'Cuento mejor y mes smene es erte inls que corro miel y leche, que meatroe denionto " $t$ "

entre cotas bellas cautives olviderein roustras amedes; hallaris aqui todos las placeres de la vida $y$ une nueve jenerscion, que sert vuentro coles on le vojor': que moraben en Stela, $Y$ fondaron Candes al orionte de la iola.

The suthority cited by Conde therefore tarms out to be no ancient Arab writer, but an Englinhman of the eightoenth century, and the figure of Al Humaidi as an athority for anything beyond the fact of the conquest and the persomality of the conqueror must diseppear from history. At flrst sight it seems impowible to soquit Conde of frend; but such a charge should not be made if eny other explanation is poseiblo: and, when we consider the diffoulties under which his work was prodaced," I think wo may bolieve that, when compiling matexial for his history, uneble to find eny Arabic account of the conquent, he wrote the paraphrase of Gibbon under the citetion from Al Dhebbi, and, when putting his work into shape, forgot the source of it and imegined it to be part of the citation. But, though all diroct Arabic suthority for the story of the burning of the ships disapposss, it still seems likely that Genesias obtained it directly or indirectly from Arab tradition. The same thing was done in this very year 828 by the Arab commander in Sicily in order to sevo his ships

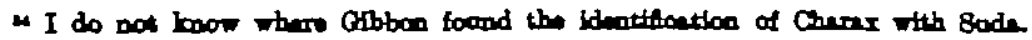

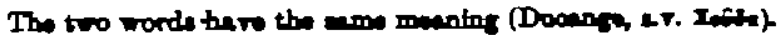

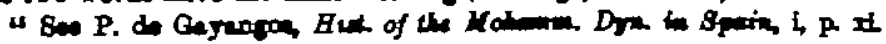


fram falling into the hends of the Romens," and the Crotan Arabe may well have tranaferred the atory to their own loader. That Genesius hed some Cretan informant $"$ soems cortain from the fact that he makes special mention of the preservation of the blood of the mertyr Cyril of Gortyne and the miracies wrought by it, and of the tomba of other local martyrs," which would not interest any ono but a netive of the inland.

Al Humaidi is clearly right in his cormine that Umar ibn Shu'eib and Shr'aib ibn 'Umar are father and som; and Shu'aib is obviounly the Eairms of Genesilus (p. 47), the weocond Arab raler of Croto. Thet Ibn Yunus calls Abu Hafi not Ibn Shu'eib bat Tbn Ise need not trouble ns, for, as Ibn Yunns himelf was by his own statement not won bat grandson of Yundi, $\infty$ either Sha"aib or 'Ine mey hevo been grandfather of Abr Eafs. The pioture which Ibn Yunas presents to ve of the pirate amir es a trevelling collector of traditions is strange one; but, as ho is said to have studied under the writer's own grandfather, the authority is good, and it is in fact anly to his literary distinction thet we owe the notice of him, for tho biographers took no acoount of any but literary men, Abu Hafe being perhaps incladed beculuse he wes confused with his son. Shn'aib's literary travels were no doubt undertaken during his father's lifotime, as we may in fuot gather from another version of the ertract from Tbn Yonus preserved by Al Sam'eni, to which I shell again refer, where the sentence in question runs: "And he used to prite before in $A l$ Traq, and ho wrote under Yunas the son of 'Abd al A Te and othere in EBypt.' Of the two detes given, 220 and 230, Fre may assome one to be a corruption of the other, and whicherer wes the original probably precerved the date of the death of Abu Hafo and succesedon of Sha'aib, which, as the two wero believed to be the same person, was supposed to be the date of the conquest. Of the two dates the later would seem the more probeble in order to allow time for Shu'cib's literary career; for, as he studied ander a men who lived till 878 and was himealf alive in $375,{ }^{\text {ol }}$ it is hard to think that his studies began before the conquest, though, as both Al Humeidi and Al Samiani give 220 in the citetion from Ibn Yunus, this dete must here been given by thet anthor. p. 19

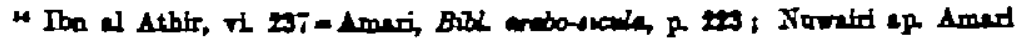

- So Bury, p. 200, n 1.

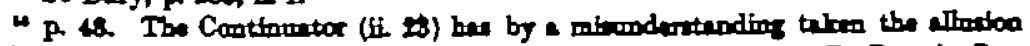

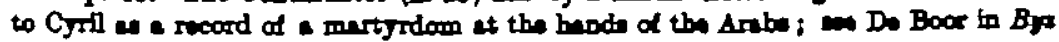
Etrituder. Iill 433.

- Theoph Cont. (r. 0) call. him Iorir.

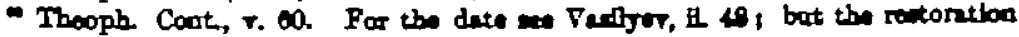

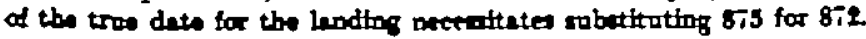


An interesting point arises from the form which the notice of Shu'aib tates in Al Sam'ani. This writer, a nativo of Merv who died in $1167^{\text {a }}$ and is independent of tho Spanish authors, composed a biographical dictionery tnown as $\boldsymbol{X}$ ilab al Anoab or Book of Surnames, in which the subjects of the notices were arranged, not as in other dictioneries in the alphebetical order of the names given to them in infancy, bat in the order of the ansab or descriptive dexignations which wero borne by many eminent Hoaloms, and especially by literary men. In this wort the misba under whioh the notice of Shn'eib is given in Al Iqritishi (tho Creten), and it bogins: "Crote. That is an island in the vestern district from which many learned men came; and the mont famous of them is Abu 'Amr Shu'aib the son of 'Umar the wn of 'Tse Al Iqritishi,' a the rest being as in Al Humaidi down to the citation given above. Ibn Yunus is not mentioned, but the notice clenrly comes trom him, and wo must aseneme that ho gavo Shn'aib tho nisba Al Iqritishi, though Al Humaidi has not preserved it." The same nioba is also ascigned by $\mathrm{Al}$ Beledhuri to Abu Hefs, ${ }^{\mu}$ and it would thereforo eppear to heve been used as a hereditary surname by the amirs of Crete. Nor Al Nawairi tells os that in the year 244 (19 April 858-7 April 859) 'Ali brother of the amir of Sicily made en expedition by during which Al Iqritishi mot him with forty ships, but 'Ali put him to flight and took ton of his ships," whilo Ibn "Adhari, though following tho same souroe, wis that 'Ali went to Creto and plondered it, but fortane then turned egainst the Moeloms, and twelve of their ships were taken." The Al Iqritishi hero mentioned is oxpposed by Amaxi 5 to have been a Romen general, and be suggeets John Creticus, orparmpós of Peloponnesur under Becil; * bat the paseages from Al Baledhori end Ibn Yunus are striking confurmation of the opinion of the older writers whom he cites that he was the annir of Crete : ho can hardly, however, have been Abu Hafs, as Ceurein do Perceval ${ }^{\infty}$ and Martorana ${ }^{\circ}$ enpposed, still bess the untrown Ahmed of Rempoldi," but ho

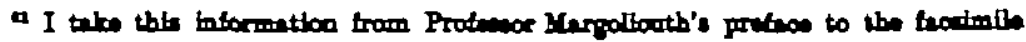

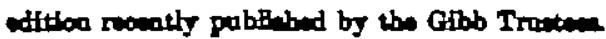

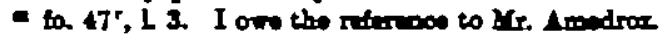

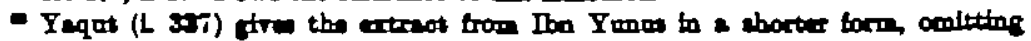

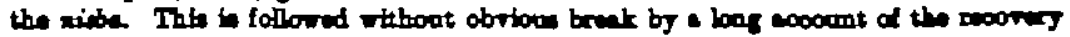

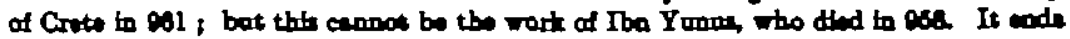

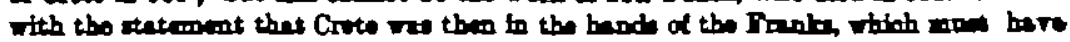
been witten atter 12ut and to probably Yequi's own additbon.

o p 2a0 (Varlyow, L epp, p 4).

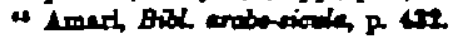

- Ed Dong, L 108 - Amard p 268.

- Storie di Iroula di Sxalie, L 220 ; tollowed by Feallyor, P. 178.

- Theoph Cont, r. or.

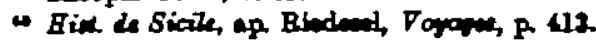

- Itaine Storiche, it as.

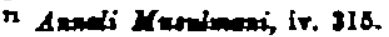


was in all probsbility Shu'aib. It coly romein to consider bor 'Ali arme into collision with the Crotan Arabs. It is very likely that the atatement of $\mathrm{Ibn}$ "Adhari that he raided Croto is a merso blunder, ${ }^{n}$ suoh a from the indirinotnea of the writing often ocours in Arabio writers; and in that ane wo may suppose thet he was raiding the meinkend of Greece or the irlands, and thet the anir of Crete, considering this as poenhing on his prewerves, attecked him. The ecoount of Ibn "Adhert is not, however, imposible. It is certatoly most unlikely that "Ali wot out vith the intention of attecking Crote: the feot that the amir hed a floot at hand rrould be auffoient to prevent thin, and, whilo there was plenty of imperiel territory to raid, it is not probable thet ho prould doliberately atteak an inland under Moalem rolo. Ho mey, however, hevo been driven by the weether to put in at Crete ; and, with men out for plunder and chort of provirions and among a population which wa matnly Christien, looting would naturally follow. Unfortunately Ibn al Athir, who ased the memo source as Al Nuwniri and Ibn 'Adheri for Sicilien affain, is hero vilent, and, as owr only Greel sowroe, tho Cembridge Chronicle,

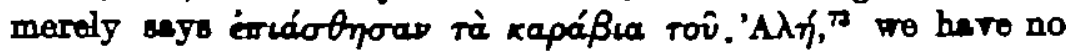
mean of determining the quection.

I conclude with another shart notice of $\Delta$ bu Hafs which follows the extract from $\Delta$ Beledhwi in Yaqut (i. 337) :

And othem berides Al Beledhwri ay : 'Crete was conquared in tho earty days of Al Hamon' [813-30], and it in aid 'It was conquored after the joar 250 [13 Pebruary 864-1 Fobruary 860] through tho inotromentelity of 'Amr the con of Bhn'aib who was called Ibo al Ghelir; and be was ono of the mea of the villege of Butroh in tho dirtriot of Paha al Beilut in Bpain, and his ino inherited it for many joen.'

This closely resembles the notion quoted from Ibn Harm by Al Hamridi. $\quad$ E. W. Broors.

Denty, p. 178, n. 4

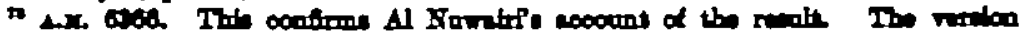

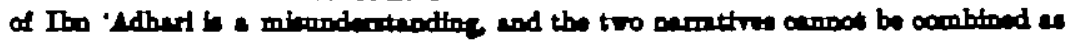

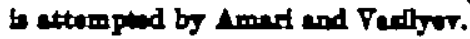

